\title{
ADDITIONAL BIRD NOTES FOR LITTLE GULL LAKE, SASKATCHEWAN
}

\author{
by Robert W. Nero, Manitoba Museum of Man and Nature, Winnipeg
}

In 1963 , incidental to botanical and rnithological studies carried out in cortheastern Saskatchewan, Dr. George W. Argus and I made a brief rip by air to Little Gull Lake near he south shore of Lake Athabasca. We were at Little Gull Lake for seven lays, from July 30 to August 5. Our tudies were supported by grants from he National Research Council of Canada and the Institute for Northrn Studies, Saskatoon.

This remote and beautiful area had arlier yielded some significant bird ecords, including a Little Gull (Larus ninutus), for which the lake was hamed, and breeding Semipalmated lover, Northern Phalarope and Horned Lark (Nero. 1963. Birds of he Lake Athabasca region, Saskathewan, Spec. Publ. No. 5, Sask. Nat. Hist. Soc.). This locality had not, lowever, previously been visited late $\mathrm{n}$ the season, hence the following bird ecords are of particular interest. Iost of our time was spent within a nile of the camp, though one day we ambled west four miles into the adjaent sand dunes. Birds were notably carce compared to previous visits. fulls, which had been so conspicuous 1952, were absent, and thus the lake seemed peculiarly quiet. No warblers were recorded, sparrows were scarce, and a solitary Robin was the only thrush observed. Evidently the southward migration, already indicated by a marked movement of birds far to the east at Stony Rapids on July 26 and 27 , was here well under way. There were, however, a few late nesting birds. For example, we found a pair of Common Loons and a Pintail hen, each with downy young, and a Red-throated Loon nest with eggs, the second for Saskatchewan. Of the 43 species observed during this period, Osprey and Sora had not previously been recorded at Little Gull Lake.

A noticeable feature was the presence of far more water in ponds out in the sand dunes than we had previously encountered. In a few cases we found a substantial growth of sedge along the pond margin and we guessed that the water had been standing a month or more. What effect this change in the habitat may have had upon the bird life within the dunes is a matter for speculation, but this observation suggests that the dunes may on occasion attract more birds than have so far been observed.

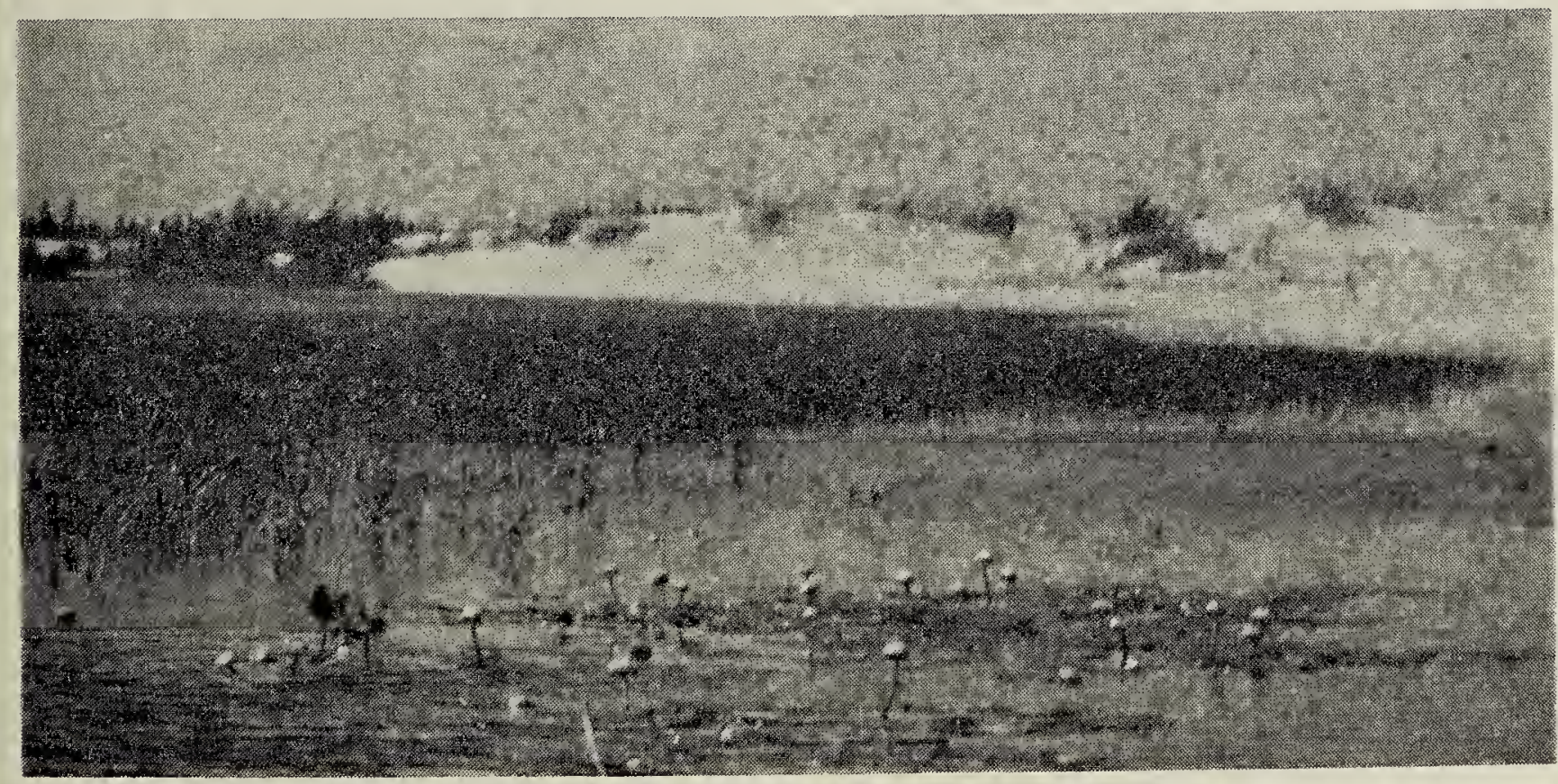

Little Gull Lake, June 30, 1962 


\section{SPECIES ACCOUNT}

Common Loon: On our arrival on July 30 a pair of loons was seen near camp where a pair had nested in the previous year; the next day we saw them out on the lake with a downy chick.

Red-throated Loon: Late in the evening of July 30 we heard one calling over the bog ponds behind our camp. On the next day two were seen on the bog ponds giving "peering" displays and we found a loon nest which appeared to be new and unused. This nest was in almost the same place as the one found in the previous year. Three loons, a male and two females, were in the area and these were seen flying together several times; they performed high, circling flights, gliding displays, and twice during the morning the "crescendo call" was heard. They were heard calling again in the early morning of August 1. I found a nest with two eggs on August 3 in a small patch of sedge out in the open in a distant pond. The freshlooking eggs rested on a bare platform formed by the mat of vegetation which comprised this remnant sedge bog. The nest was almost at water level and the eggs were only six inches from the edge of the water. It seemed an odd place to build a nest, in view of the numerous small bog islets of Sphagnum moss, etc., which were nearby. Two eggs were still present when we checked the nest on August 4; on the following day we left the area. It would have been of interest to know the date of hatching of this late clutch.

In the morning and evening of August 4 we were treated to a distant chorus of vocalizations from the loons, two, or possibly all three, repeatedly calling together in a medley of plaintive, wailing, cat-like "merows"; then one, presumably the male, began giving the harsh, raucous "growling call" against the background of continued "merowing", producing a weird and wonderful effect.

The next morning, on our last day on Little Gull lake, the male flew up over the lake into the face of a storm; as it rose against the dark clouds it gave the harsh, rolling "gruk-gruk ... grrruk ..." call.

Mallard: A hen with seven fullygrown young, and three adults, July 31 ; a hen with two young about $2 / 3$ grown, on the small lake to the south, August 4.

Pintail: A female with a brood of five or six downy young in the bog pond area, July 31 . This record provides the first definite evidence of breeding for this species in northern Saskatchewan.

Green-winged Teal: A female with a brood of four, almost adult size, July 30.

American Widgeon: One on August 4 on the small lake just south of Little Gull Lake.

Ring-necked Duck: July 30, a female with a brood of five, several weeks old. July 31 , a female with a brood of seven, about two weeks old; and a group of four females with broods which were already mixed when we sighted them late in the evening-there were 16 young, from one to three weeks of age. August 2, a pair on the lake. August 4, a female with a brood of four on a small lake south of Little Gull Lake.

Lesser Scaup: July 30, a female, in the bog ponds; July 31, a female, perhaps the same one, with a brood of five, about $1 / 4$ grown.

Bufflehead: July 30, a female with only one young, about $1 / 3$ grown; July 31 , a female with four young, $1 / 3$ grown; August 4, a single female.

Surf Scoter: August 2, female with a brood of six, nearly full-grown, and another female with a brood of four, about 1/2 grown; August 3, these two females were seen in mid-afternoon close together, moving their families out into the centre of the lake.

Red-tailed Hawk: Several times late in the evening of July 31 near the bog ponds I heard a hawk call that sounded like a red-tail.

Bald Eagle: An immature eagle was seen on August 4.

Marsh Hawk: A male hunting low over the bog ponds on July 31 showed an immediate response and flew in to look at me when I made a squeaking 
sound. One was seen at a distance on August 2.

Osprey: One was seen flying low over the bog ponds late in the evening of July 30 . Another was seen on August 3.

Pigeon Hawk: Late in the evening of July 30 while we were walking in the dunes adjacent to Little Gull Lake, a Pigeon Hawk suddenly appeared flying steadily toward us; it dropped down at the last moment so that it peered right into our faces just before it lifted and flew over our heads-it was a lovely, tense moment. I recorded two on July 31, and Argus reported a family group out on the dunes on the same day. Late in the evening of August 1, we saw two, evidently a pair, in "play" over the bog ponds - moving slowly across the ponds, intermittently swooping up and hovering together, then one gliding down and away from the other.

Sparrow Hawk: One with three fledged young July 31 and again on August 2.

Spruce Grouse: July 31, a family group, young nearly full-grown.

Sandhill Crane: We saw three Sandhill Cranes in flight about 10 miles east of Little Gull Lake from our plane while en route to our camp on July 30. The next day at camp we heard cranes calling early in the morning. On August 2, a flock of four, evidently a pair with two young, flew directly over our camp early in the morning. We saw this group again later in the day and also found their tracks in the sand dunes northwest of camp; their "probe-marks" were seen in several damp places in the sand where they had walked, and we wondered what they were finding. Two additional cranes were seen on August 4 on the big bog meadow south of Little Gull Lake, exactly where two were seen in 1961.

Sora: We flushed a Sora from a bog on the east side of Little Gull Lake on August 3.

Semipalmated Plover: Three shorebirds seen flying over the dunes (where previously recorded breeding) at Little Gull Lake on July 31, and one on August 1 were judged to be of this species. One was seen feeding on a beach at a small lake to the south on August 4.

Common Snipe: July 31, one gave distraction display in suitable nesting habitat and was presumed to be nesting; August 4, one in another place.

Greater Yellowlegs: August 1, a pair with an immature which could fiy well were found deep within the dunes near small ponds. On August 4, one was seen on the small lake south of Little Gull Lake.

Baird's Sandpiper: Three shorebirds seen in flight at close range near ponds deep within the sand dunes west of little Gull Lake on August 1 were believed to be of this species, but this is a poor record.

Least Sandpiper: Records at Little Gull Lake in 1961 and 1962 and again in 1963 suggest the possibility that the Least Sandpiper may breed here. There are uncertain late season records (in 1963) for July 31 (a bird overhead), and August 1 (three overhead). On August 4, 1963 while walking along the edge of the dunes and beside a sedge bog south of our camp we flushed two sandpipers which by behaviour appeared to be an adult and a juvenile. After flying about briefly they returned and landed near us and the juvenile was collected. It was found to have a trace of down at the base of both mandibles, and the feet were a dull, brownish color. Later in the day a second immature bird, in the same plumage as the one collected, flew in and landed on a small, shallow pond far out in the dunes. When I approached the pond the bird walked toward me, feeding as it moved along; several times it approached to within three feet of me. The confiding nature of the Least Sandpiper has long been known (e.g., described by D. G. Elliot, 1895. North American Shore Birds. Francis Harper, N.Y.), but I found this bird difficult even to put to flight, and therefore felt that it might have been raised nearby. Certain other shorebirds which we found in the area during this period were undoubtedly migrants, e.g., a Semipalmated Sandpiper which was collected on August 1 (an immature), 
and small flocks of larger shorebirds (probably Baird's and Pectoral sandpipers) which were seen in flight over the dunes on August 1 and 4. Hence our Least Sandpipers could well have been migrants from the northeastern area. Further evidence of a migration of shorebirds was seen a few days later at Stoney Rapids, where unidentified "peeps", i.e., small sandpipers, either Least or Semipalmated, were seen. On August 6 a flock of eight flew in to the edge of the river beside the dock. They landed on some willow brush lying in the water and also waded in the shallows, but flew before I could get close. Three were seen fiying over the river on August 7, and two were seen by a puddle on the airstrip when we were preparing to depart. There are, as well, earlier records of what were presumed to be fall migrants. A lone Least Sandpiper was seen by Lein and Sanderson at the dock at Stony Rapids, July 25 and July 26, 1964. Migrant shorebirds were noted by them earlier, a flock of four Pectoral-sized sandpipers having been seen flying down the Porcupine River on July 12, 1964. Thus there remains a lack of clear-cut evidence for breeding of the Least Sandpiper in the Lake Athabasca area, although their breeding here seems not improbable, especially in view of records in this locality of breeding Semipalmated Plover and Northern Phalarope.

Semipalmated Sandpiper: On August 1 , I collected an immature female at a small pond in the sand dunes about $3 \frac{1}{2}$ miles west of Little Gull Lake. A double layer of bone was just beginning to develop on the cranium. Another one, in similar plumage, was closely observed on a sandy beach on the small lake just south of Little Gull Lake, August 4. On this latter date migrant shorebirds were clearly present, and these Semipalmated Sandpipers were undoubtedly transients.

Bonaparte's Gull: A single Bonaparte's Gull in immature plumage was seen flying over the dunes and out onto the small lake south of Little Gull Lake on August 4, but we saw no other gulls during the period of our visit.
Arctic Tern: July 31, three which were seen flying over the lake were presumed to be of this species. I saw an adult accompanied by an immature which was still begging for food, out on the lake, and three in the dunes on August 1.

Great Horned Owl: A freshly-shed feather from a Great Horned Owl was found on the edge of the dunes at Little Gull Lake, August 4.

Common Nighthawk: Two were seen on July 31.

Yellow-shafted Flicker: Two records, July 31 and August 2.

Olive-sided Flycatcher: One was identified by its distinct call on August 4.

Gray Jay: Three or more were recorded on each of three days, July 30 , July 31 and August 2.

Common Raven: August 1, one; on August 4 we saw a group of four out in the dunes walking about and picking up something on the open sand, perhaps insects.

Common Crow: July 31, evidently a family group of five, seen about the bog ponds.

Boreal Chickadee: A family group on July 31, another on August 2.

Robin: On August 3, I saw a Robin on the large island, but no others were noted.

Rusty Blackbird: A family group was seen on August 2, an adult on August 4.

Common Redpoll: Several, presumably of this species, were heard overhead on July 31 ; several were heard in the jack pine and birch clumps in the dunes on August 1.

Savannah Sparrow: July 30, two; August 4, a family group.

Slate-colored Junco: July 31, one, and a family group; August 2, another family group.

Chipping Sparrow: Two were seen in the dunes, August 1; one south of camp, August 4.

White-crowned Sparrow : Two family groups were seen in birch-pine depressions in the sand dunes, August 1.

Lincoln's Sparrow: July 31, one; August 2, one in brief song early in the morning at our camp; August 4, one. 